\title{
Physiochemical properties, sensory evaluation and shelf life of corn flour supplemented with Acheta gossypii (cricket) flour
}

\author{
Elijah Edache Ehoche ${ }^{1 a^{*}}$, Akanya Oluwafunmi $^{1 \mathrm{~b}}$, Adefolalu Folasade Oluwafunmilola $^{1 \mathrm{c}}$ \\ ${ }^{1}$ Department of Biochemistry Federal University of Technology, Minna, Nigeria \\ a Email address: elaijahee@gmail.com \\ b Email address: funmiakanya@yahoo.com \\ c Email address: adefolalu@futminna.edu.ng
}

\section{HIGHLIGHTS}

Cricket supplemented flour was more acceptable than sensory evaluation.

\section{ARTICLE INFO}

\section{Article history}

Received date: January $08^{\text {th }}, 2019$

Revised date: March $25^{\text {th }}, 2019$

Accepted date: Mei $02^{\text {nd }}, 2019$

\section{Keywords:}

Diet

Sensory

Shelf life

Physiochemical

\begin{abstract}
A B S T R A C T / A B S T R AK
Most consumed diets are made from corn and are deficient in proteins. Corn flour was made from fermented and dried yellow corn and supplemented with 5 and $10 \%$ proteins of crickets. The diets were analyzed for the following physiochemical properties: swelling index, wettability, bulk density, solubility, and water holding capacity as well as sensory characteristics in a 7 point hedonic scale and the maintaining quality of each diet. Standard methods for physiochemical properties were used, and the microbial assay was also to analyze the diets at refrigerated and non-refrigerated conditions. The swelling index $(1.83-2.00 \mathrm{~g})$, gelatinization temperature $\left(66.3-72.3^{\circ} \mathrm{C}\right)$, wettability $(22.0-120$ seconds), and bulk density $(0.59-0.67 \mathrm{mg} / \mathrm{mL})$, significantly increased but solubility $(14.1-3.00 \%)$, and oil-water holding capacity ( 90-65 \%) reduced significantly in the cricket supplemented diets over the corn flour $(p<0.05)$. The sensory characteristics from both the adult and children scored above average on the 7 points hedonic scale, with a major preference for the $5 \%$ cricket supplemented the diet. It is noteworthy that in the 4 weeks of shelf life experiment, all the diets were found to be devoid of the growth of coliforms, yeast and the only occurrence of the mold is below the harmful threshold except with the $10 \%$ cricket supplemented non-refrigerated diet with the growth of $B$. subtilis on the $3^{\text {rd }}$ week of the experiment. However, the growth of this bacterium is below a harmful threshold. Proper handling and processing are safest before consumption. Supplementations of corn flour with cricket have been found to improve the nutritional quality of corn and may, therefore, be able to solve the problem of malnutrition.
\end{abstract}

This journal is an open-access article under the CC-BY-SA license.

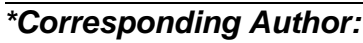

Elijah Edache Ehoche

Department of Biochemistry

Federal University of Technology, Minna, Nigeria

Email: elaijahee@gmail.com
} 


\section{INTRODUCTION}

Availability of food for consumption remains a significant concern of the world. ${ }^{1}$ This is because global malnutrition level is still high ${ }^{2}$ most consumed diets are made of staples which are deficient in nutrients; especially the cereals may lead to malnutrition. ${ }^{3}$ Cereals such as maize, rice, millet, sorghum, oats, barley and wheat; in gravy, paps, milk or tea and rice are widely consumed around the world. ${ }^{4}$ Maize is one of the essential staple diets of the Nigerian population ${ }^{5}$ and third most used after rice and sorghum. ${ }^{4}$ The proximate composition of the grains showed that maize contained low levels of crude protein and fat but high levels of carbohydrate and therefore, require supplementation for increased protein composition. ${ }^{6}$ Crickets and other insects are a good source of proteins. $^{7}$

However, insects, and specifically crickets, have long been overlooked and underutilized as a source of an essential nutrient in the modern world. Many species have been researched on, and the nutritional values determined. These include species such as the field cricket (Gryllus genus), and the house cricket (Acheta genus). Thailand's field cricket Gryllus bimaculatus (raw), for example, contains an energy value of $120 \mathrm{kcal} / 100 \mathrm{~g}$, which is comparable to the 150 kilocalories per $100 \mathrm{grams}$ of skinless chicken breast. The proximate protein and fat composition of a single field cricket (Gryllus genus) is also $58 \%$ protein and $10 \%$ fat. The composition of single house cricket (Acheta domestica) is higher $65 \%$ protein and $20 \%$ fat. ${ }^{8}$ Field crickets provide more than the minimum amino acid profile reported by the World Health Organization in order to be an adequate source of essential amino acids. In one study, it was observed that the protein of the house cricket was superior to soy protein for amino acid intake when fed to rats. ${ }^{9}$ Vitamin $B_{12}$, which is only naturally present in food of animal origin, andis vital for human health, is found in sufficient amounts in house crickets $(5.4 \mu \mathrm{g}$ per $100 \mathrm{~g}$ in adults and 8.7 $\mu \mathrm{g}$ per $100 \mathrm{~g}$ in nymphs); the recommended dietary amount is $2.4 \mu \mathrm{g}$ daily. ${ }^{10}$ The mineral composition of insects is also comparably high. The majority of insects show high amounts of potassium, calcium, iron, magnesium, and selenium, as well as zinc. Acheta domesticus contains about six to eleven milligram of iron per 100 gram while ground beef contains about 2.2 milligrams of iron per 100 gram. ${ }^{11}$ This makes cricket a suitable alternative to conventional meat such as beef products ${ }^{12}$ for supplementation of protein deficient staples.

As with all other edible products, the safety of consuming cricket products is an important question to reflect on. ${ }^{10}$ One presumption on why there is such a prevalent caution against edible insects is that the swing from hunting and gathering to a more sedentary farming routine resulted in the view of insects as pests besides a risk to health. ${ }^{13}$ If the safety of insect-related foods as related to processing, preservation, packaging is considered and found healthy, the consumption can be enhanced. ${ }^{14,15,16}$ Neo-phobia for foods is another determinant of subjects' interest to eat insect-based food. ${ }^{17}$ The essential factor in promoting entomophagy (compared to pricing, value, profit, risks, naturalness, confidence, approach, and traditions) is the opportunity for sensory evaluation. ${ }^{13}$ Hence crickets could add its nutritious value to the vast array of foods targeted for supplementation.

\section{MATERIALS AND METHOD}

All the chemicals used were of general purpose grade manufactured by the British Drug House $(\mathrm{BDH})$ Limited, Poole, England, and Sigma Aldrich Chemical Company Incorporation, Wisconsin, USA.

\subsection{Samples Treatment}

The (Yellow) corn (Zea mays) samples were bought from Maikunkele Market, Bosso Local Government, Minna, Niger State. The roasted cricket (Acheta gossypii) flour sample was commercially obtained from Ankpa roadside market, Ankpa local 
Government, Kogi State, Nigeria. Both the (Yellow) corn (Zea mays) and the cricket (Achetagossypii) samples were also identified in the Department of Animal Biology, Federal University of Technology, Minna, Nigeria. The cricket roasted cricket flour after the collection was stored in plastic containers for analyses. The corn kernels were cleaned, steeped in a plastic container to ferment for 68 hours to allow for fermentation without sprouting. The fermented product was rinsed with clean tap water and sundried after which they were wholly ground severally to powder using an electric grinder (Henry west G160, 5.5 HP). This was kept in a plastic container for further analyses.

The diets were formulated into 5 and $10 \%$ cricket supplements based on the percentage inclusion of 5 and $10 \%$ proteins from cricket. The formulation was done based on the \% protein content of the original fermented corn and cricket flour respectively to yield an increment of 5 and $10 \%$ cricket content in the experimental diets. The diets were kept in plastic containers for further analyses. Paps were made from the corn flour, $5 \%$ and $10 \%$ cricket supplemented diets. Each pap sample was made with the powdered diets $(4 \mathrm{~g})$ containing $1 \mathrm{~g}$ of sugar and $6 \mathrm{~mL}$ of boiling water. This was used for sensory evaluation.

\subsection{Physiochemical Properties}

Food physiochemical properties are those food characteristics that describe how food responds to physical, thermal, and chemical treatments. These properties use various methods to define, quantify, and predict the behavior of new food material that is useful in determining food quality and safety. The properties carried out in the experiment (includes: bulk density, wettability, oil, and water absorption capacity, solubility temperature, and swelling index) of the corn and cricket supplemented diets.

\subsection{Determination of bulk density}

The method described by Onwuka ${ }^{18}$ was adopted. The determination was carried out by placing each sample $(50 \mathrm{~g})$ into $100 \mathrm{~mL}$ measuring cylinder, making sure that the sample was well compacted ( by knocking the bottom of the cylinder). The absolute value obtained was recorded in $\mathrm{mg} / \mathrm{mL}$. This is given as:

Bulk density $\quad=\quad$ Bulk mass $(\mathrm{mg})$ Bulk Mass $(\mathrm{mg})$ Bulk volume $(\mathrm{mL})$...equation 1

\subsection{Determination of wettability}

The method described by Onwuka ${ }^{18}$ was used for the determination. Each sample $(1 \mathrm{~g})$ was measured into a measuring cylinder $(25 \mathrm{~mL})$ whose diameter is $1 \mathrm{~cm}$. The cylinder was inverted and clamped at $10 \mathrm{~cm}$ directly above the surface of $600 \mathrm{~mL}$ beaker containing distilled water $(500 \mathrm{~mL})$ as a finger was placed at the open end. Then the finger was removed, and the sample was allowed to be let into the water. The time taken for each sample to be thoroughly wet was noted.

\subsection{Determination of oil and water absorption capacity}

The method described by Sandra ${ }^{19}$ was used to determine the oil and water absorption capacity of the samples. Using Oil (whose density is $0.9 \mathrm{~g}$ per $\mathrm{mL}$ ) and or water $(1 \mathrm{~g}$ per $\mathrm{mL})$, the absorption capacity is given by the volume of a supernatant left after the sample and water are well mixed. Distilled water $(10 \mathrm{~mL})$ was added to each sample $(1 \mathrm{~g})$. The combination was carefully mixed for 60 seconds and left to stand for 30 minutes, and time the volume of the supernatant was recorded. The volume of the supernatant obtained is equal to the oil and water absorption capacity.

\subsection{Determination of solubility}

The method of Udensi and Onuora ${ }^{20}$ was adopted. Dispersion of powder (10\% $\mathrm{w} / \mathrm{v}$ ) of each of the samples in distilled water was made by spreading $1 \mathrm{~g}$ of dry sample 
powder in $5 \mathrm{~mL}$ of distilled water and made up to $10 \mathrm{mLs}$ then left to stand for 1 hour being stirred every 10 minutes. After that, it was left to stand for another 15 minutes then filtered. The filtrate ( $2 \mathrm{~mL}$ each) was weighed in a Petri-dish (clean and dry) heated to evaporation and reweighed. The difference in mass is the total soluble solids.

Solubility $=$ TSS $(\%)((V s M e-M d) \times 100) / 2 M s$ X 1 equation 2

Where

TSS $=$ Total soluble solids

Vs $=$ Total supernatant/ filtrate

$\mathrm{Md}=$ Mass of empty, dry Petri dish

$\mathrm{Me}=$ Mass of Petri dish plus residual solid after evaporative drying

$\mathrm{Ms}=$ mass of powder sample used in the preparation of the dispersion.

\subsection{Determination of pasting temperature}

The method of Nwosu ${ }^{21}$ was modified and used. On heating, the starch granules (and protein molecules) absorb water molecules and form paste gels at a given range of temperature (gelatinization temperature). The temperature at which gelatinization onsets is the pasting temperature. Each powder $(1 \mathrm{~g})$ sample was dispersed in distilled water $(5$ $\mathrm{mL}$ ) contained in a test-tube and heated in a water bath. The temperature of the onset of gelatinization was noted and recorded.

\subsection{Determination of swelling index}

The method described by Ukpabi and Ndimele was used for the analysis. ${ }^{22}$ Dry powder portions $(3 \mathrm{~g})$ each was put into dry clean $50 \mathrm{~mL}$ graduated cylinders, and the initial volume noted after being carefully leveled. Each sample was then made up to $30 \mathrm{~mL}$ with distilled water. The content was shaken then let to rest for 1 hour while the change in volume (swelling) was noted for every 15 minutes.

\subsection{Determination of organoleptic Score}

The nutritional quality of a new diet is also a function of the sensory evaluation and opinion of panelists familiar with a similar diet by the aid of their senses of sight, feel, smell, and taste. In this work, the 7-grade organoleptic score was used according to Adegunwa. ${ }^{22}$ A panel of adults (10) familiar with pap was constituted. Each person in the panel was served a pap sample and given a score sheet to mark their like or dislike. Another panel of 10 was set up for children familiar with pap. For the children, it was slightly modified with smileys where they marked their like or dislike. A seven-point scale was determined in a scale where 7 scored highest. The seven-point sensory score was based on general appearance, color, smell, taste, texture, and general acceptance. Informed consent of the parent, guardian of the children, and the ethical committee of the Federal University of Technology, Minna was obtained.

\subsection{Determination of Shelf Life}

The corn flour and the cricket supplemented diets were analyzed for shelf life. The shelf life for each sample was monitored at both refrigerated and room temperatures using microbial analysis. The spread plate method, as described by Ambreen, was used. ${ }^{23}$ The spread plate method allows the secure transfer and quantifying of microorganisms on reliable mediums.

Both refrigerated and non-refrigerated powder samples were stored for 28 days and analyzed every seven days. Sample serial dilution was set up by the weighing of 1 $\mathrm{g}$ of each sample to $9 \mathrm{~mL}$ of sterilized phosphate buffer in the test tube. Following every dilution, the contents were blended for 10 seconds in a vortex mixer. $1 \mathrm{~mL}$ from each 
dilution was added into a plate count agar in a petri dish and mixed thoroughly. Once solidification was achieved, the Petri dishes were incubated at $35^{\circ} \mathrm{C}$ for 48 hours for total plate count and colonies formed on the surface and in the media were calculated as colony forming unit (CFU per $\mathrm{mL}$ ). For coliform, fungi (yeast), and mold counts the spread plate technique was also used. However, In the determination of counts for coliform, MCA (Macconkey agar) was used while that of yeast and mold was done using SDA (sabouraud dextrose agar) respectively. The Yeast growth was corrected by 40 ppm Chloramphenicol (put in as antibacterial agent) whereas only sabouraud dextrose agar was utilized for molds recognition. The media was incubated at $25^{\circ} \mathrm{C}$ for 96 hours.

\subsection{Statistical Analysis}

Data obtained were subjected to statistical analysis for the determination of mean and standard deviation values using Microsoft Excel. Separate determinations for the significant differences $(p<0.05)$ between the mean values were analyzed using the Duncan's Multiple Range Test.

\section{RESULTS AND DISCUSSION}

The physiochemical properties of the diets are shown in Table 1. The swelling index ranged between 1.83 to $2.00(\mathrm{~g} / \mathrm{g}$ ) with the $10 \%$ cricket diet having the highest value while the $5 \%$ cricket supplemented diet had the lowest. There was no significant difference between the swelling index of corn flour and the $5 \%$ cricket supplemented diet $(p>0.05)$. The corn flour diet had the lowest solubility $(\%)$ while the $10 \%$ cricket supplemented diet had the highest solubility, which was significant from the other diets $(p<0.05)$.

There was also a significant difference in the gelatinization temperature of the diets $(p<0.05)$. It was lowest in the, and highest in the $10 \%$ cricket supplemented the diet. The wettability and bulk density of each diet sample follows the same trend as the solubility. However, the difference in bulk density between the cornflour and the $5 \%$ cricket supplemented diet was not significant $(p>0.05)$. The oil or water absorption capacity varied significantly $(p<0.05)$ in all the diets. The corn flour had the highest oil, while the $10 \%$ percent cricket diet has the least value (Table 1).

Table 1. Physiochemical Properties of the Experimental Diets

\begin{tabular}{lllllll}
\hline Diet & $\begin{array}{l}\text { Swelling } \\
\text { index }(\mathrm{g} / \mathrm{g})\end{array}$ & $\begin{array}{l}\text { Solubility } \\
(\%)\end{array}$ & $\begin{array}{l}\text { Gelatinization } \\
\text { Temperature } \\
\left({ }^{\circ} \mathrm{C}\right)\end{array}$ & $\begin{array}{l}\text { Wettability } \\
(\text { seconds) }\end{array}$ & $\begin{array}{l}\text { Oil/Water } \\
\text { absorption } \\
\text { capacity } \\
(\%)\end{array}$ & $\begin{array}{l}\text { Bulk } \\
\text { density }(\mathrm{mg} / \mathrm{mL})\end{array}$ \\
\hline $\begin{array}{l}\text { Corn } \\
\text { flour }\end{array}$ & $1.92 \pm 0.40^{\mathrm{a}}$ & $14.0 \pm 1.50^{\mathrm{c}}$ & $66.3 \pm 0.70^{\mathrm{a}}$ & $22.0 \pm 12.0^{\mathrm{a}}$ & $90 \pm 10.0^{\mathrm{c}}$ & $0.59 \pm 0.09^{\mathrm{a}}$ \\
$\begin{array}{l}5 \% \\
\text { cricket }\end{array}$ & $1.83 \pm 0.50^{\mathrm{a}}$ & $9.00 \pm 1.50^{\mathrm{b}}$ & $68.0 \pm 0.01^{\mathrm{b}}$ & $60.0 \pm 12.0^{\mathrm{b}}$ & $70 \pm 12.0^{\mathrm{b}}$ & $0.62 \pm 0.08^{\mathrm{a}}$ \\
$\begin{array}{l}10 \% \\
\text { cricket }\end{array}$ & $2.00 \pm 0.80^{\mathrm{a}}$ & $3.00 \pm 0.80^{\mathrm{a}}$ & $72.3 \pm 0.70^{\mathrm{c}}$ & $120 \pm 15.0^{\mathrm{c}}$ & $65 \pm 10.0^{\mathrm{a}}$ & $0.67 \pm 0.08^{\mathrm{b}}$ \\
\hline
\end{tabular}

Values are means ( \pm Standard deviation) of triplicate determinations. Values with different superscript along each column are significantly different from each other $(p<0.05)$.

Tables $2 a$ to 2 e show the microbial content of the experimental diet during storage. At the onset of the experiment (Table 2a), there was no identified bacterial, coliforms, and fungal count on the cornflour diet. However, both the $5 \%$ and $10 \%$ cricket diet showed the growth of Lactobacillus bulgaricus a fermentation microbe. The $10 \%$ cricket supplemented diet additionally grew Micrococcus luteus. The organism identified were not in the list of those mentioned the Food and Drug Agency (FDA) to affect food safety. 
Storage for one week at refrigerated temperature and room temperature (average of 24.9 ${ }^{\circ} \mathrm{C}$ ) is shown in Table $2 \mathrm{~b}$. There was no microbial growth in the cornflour diet both at room temperatures refrigerated and at conditions. The total viable count for bacteria in the cricket diet was found to be lower than in week 1 . The values in the shelved diets were much higher than the refrigerated diet. There was no significant difference between the $5 \%$ cricket (shelved) and $5 \%$ cricket(refrigerated) diets, but the shelved $10 \%$ cricket supplemented diet was significantly higher than the $10 \%$ cricket(refrigerated) diets $(p<$ 0.05).

Table $2 \mathrm{c}$ shows that the cornflour diet still had no microbial growth after two weeks of storage. The total microbial count in the $5 \%$ cricket diets was decreased, especially in the refrigerated diet, which had the lowest count. There was no significant difference between the total fungal count in the $5 \%$ cricket diets (refrigerated) and $5 \%$ cricket diets (shelved). However, the fungal count increased in the $10 \%$ cricket with the $10 \%$ cricket proteins (shelved) diets having the highest load $(\mathrm{p}<0.05)$. The result for microbial assay for the third week is as shown in Table $2 \mathrm{~d}$. The corn flour diet remained free of microbes while the bacterial counts of the $5 \%$ cricket diets (shelved) $5 \%$ cricket diets (refrigerated) and $10 \%$ cricket diets (refrigerated) diets are not significantly different( $p>0.05)$. However, the bacterial count in the $10 \%$ cricket supplemented diet (shelved) was higher than the other diets as it indicated the growth of Micrococcus luteus, Lactobacillus bulgaricus, Bacillus subtilis, and Aspergillusniger.

The result for microbial assay for the fourth week is as shown in Table $2 \mathrm{e}$. In the corn flour diet (shelved), there was an appearance of Bacillus subtilis although within the safe limit for Bacilus subtilis. In the $5 \%$ cricket supplemented diet (shelved), the growth of Lactobacillus bulgaricus was reduced but increased in the $10 \%$ cricket diets (refrigerated). The $5 \%$ cricket supplemented diet (refrigerated) had a lower growth of bacteria than in the $10 \%$ cricket diets (refrigerated), which was significantly different ( $p$ $<0.05)$. The growth of the fungus, Mucor species was also noticed in the $5 \%$ cricket supplemented diet (refrigerated) for the first time in the experiment.

Table 2a. Microbial Content of the Diet at Onset of Storage (week 0)

\begin{tabular}{|c|c|c|c|c|}
\hline Sample & $\begin{array}{l}\text { TVC } \times 10^{3} \\
(\mathrm{cfu} / \mathrm{g}), \mathrm{NA}\end{array}$ & $\begin{array}{l}\text { TCC } \times 10^{3} \\
(\mathrm{cfu} / \mathrm{g}), \mathrm{MCA}\end{array}$ & $\begin{array}{l}\text { TFC } \times 10^{3} \\
(\mathrm{cfu} / \mathrm{g}), \\
\text { SDA }\end{array}$ & $\begin{array}{l}\text { Microorganism } \\
\text { Identified }\end{array}$ \\
\hline Corn flour & Undetected & Undetected & Undetected & None \\
\hline $5 \%$ cricket & $4.09 \pm 0.2^{a}$ & Undetected & Undetected & Lactobacillus bulgaricus \\
\hline $10 \%$ cricket & $3.00 \pm 0.1^{b}$ & Undetected & Undetected & $\begin{array}{l}\text { Micrococcus luteus, } \\
\text { Lactobacillus bulgaricus }\end{array}$ \\
\hline $\begin{array}{l}\text { *Standard } \\
\text { safe limit }\end{array}$ & $0.10(a)$ & $0.01(b)$ & $10(c), 0.1(d)$ & $\begin{array}{l}\text { (a) Bacillus subtilis } \\
\text { (b) Coliforms } \\
\text { (c) Mould } \\
\text { (d) Saccharomyces spp }\end{array}$ \\
\hline
\end{tabular}

Values are means ( \pm Standard deviation) of triplicate determination. Values with different superscript along the column are significantly different from each other $(p<0.05)$. Alphabet in brackets represents organisms identified.

Key:

TVC -total viable count using nutrient agar (NA) for general bacterial

TCC - total coliforms count using MCA (Macconkey agar)

TFC -total fungal count using SDA (sabouraud dextrose agar)

cfu/g - colony forming units (S.I unit of microbial count) per gram of sample 
Table 2b. Effect of Storage on the Microbial Content of the Experimental Diets (Week 1)

\begin{tabular}{|c|c|c|c|c|}
\hline Sample & $\begin{array}{l}\text { TVC } \times 10^{3} \\
(\mathrm{cfu} / \mathrm{g}), \mathrm{NA}\end{array}$ & $\begin{array}{l}\text { TCC } \times 10^{3} \\
(\mathrm{cfu} / \mathrm{g}), \mathrm{MCA}\end{array}$ & $\begin{array}{l}\text { TFC } \times 10^{3} \\
(\mathrm{cfu} / \mathrm{g}), \text { SDA }\end{array}$ & $\begin{array}{l}\text { Microorganism } \\
\text { Identified }\end{array}$ \\
\hline $\begin{array}{l}\text { Corn flour, } \\
\text { shelved }\end{array}$ & Undetected & Undetected & Undetected & None \\
\hline $\begin{array}{l}5 \% \text { cricket, } \\
\text { shelved }\end{array}$ & $2.70( \pm 0.08)^{\mathrm{c}}$ & Undetected & Undetected & Lactobacillus bulgaricus \\
\hline $\begin{array}{l}10 \% \text { cricket, } \\
\text { shelved }\end{array}$ & $1.70( \pm 0.08)^{\mathrm{b}}$ & & & $\begin{array}{l}\text { Micrococcus luteus, } \\
\text { Lactobacillus bulgaricus }\end{array}$ \\
\hline $\begin{array}{l}\text { Corn flour, } \\
\text { refrigerated }\end{array}$ & Undetected & Undetected & Undetected & None \\
\hline $\begin{array}{l}5 \% \text { cricket, } \\
\text { refrigerated }\end{array}$ & $2.60( \pm 0.1)^{\mathrm{c}}$ & Undetected & Undetected & Lactobacillus bugaricus \\
\hline $\begin{array}{l}10 \% \text { cricket, } \\
\text { Refrigerated }\end{array}$ & $1.30( \pm 0.02)^{a}$ & Undetected & Undetected & Lactobacillus bulgaricus \\
\hline $\begin{array}{l}\text { *Standard } \\
\text { safe limit }\end{array}$ & $0.10(a)$ & $0.01(b)$ & $10(c), 0.1(d)$ & $\begin{array}{l}\text { (a) Bacillus subtilis } \\
\text { (b) Coliforms } \\
\text { (c) Mould } \\
\text { (d) Saccharomyces spp }\end{array}$ \\
\hline
\end{tabular}

Values are means ( \pm Standard deviation) of triplicate determinations. Values with different superscript along the columns are significantly different from each other $(p<0.05)$. Alphabet in brackets represents organisms identified.

Table 2c. Effect of Storage on the Microbial Content of the Experimental Diets (week 2)

\begin{tabular}{|c|c|c|c|c|}
\hline Sample & $\begin{array}{l}\text { TVC } \times 10^{3} \\
(\mathrm{cfu} / \mathrm{g}), \mathrm{NA}\end{array}$ & $\begin{array}{l}\text { TCC } \times 10^{3} \\
(\mathrm{cfu} / \mathrm{g}), \mathrm{MCA}\end{array}$ & $\begin{array}{l}\text { TFC } \times 10^{3} \\
(\mathrm{cfu} / \mathrm{g}), \text { SDA }\end{array}$ & $\begin{array}{l}\text { Microorganism } \\
\text { Identified }\end{array}$ \\
\hline $\begin{array}{l}\text { Corn flour, } \\
\text { shelved }\end{array}$ & Undetected & Undetected & Undetected & None \\
\hline $\begin{array}{l}5 \% \\
\text { cricket, } \\
\text { shelved }\end{array}$ & $\begin{array}{l}1.20 \pm 0.09^{b} \\
\text { (a) }\end{array}$ & Undetected & $0.20 \pm 0.03^{a}(b)$ & $\begin{array}{l}\text { (a) Lactobacillus bugaricus, } \\
\text { (b) Muccorpussillus }\end{array}$ \\
\hline $\begin{array}{l}10 \% \\
\text { cricket, } \\
\text { shelved }\end{array}$ & $\begin{array}{l}18.0 \pm 1.0^{c} \\
(a, b)\end{array}$ & Undetected & $0.70 \pm 0.01^{b}(c)$ & $\begin{array}{l}\text { (a) Lactobacillus bulgaricus, } \\
\text { (b) Bacillus subtilis and } \\
\text { (c) Aspergillusniger }\end{array}$ \\
\hline $\begin{array}{l}\text { Corn flour, } \\
\text { refrigerated }\end{array}$ & Undetected & Undetected & Undetected & None \\
\hline $\begin{array}{l}5 \% \\
\text { cricket, } \\
\text { refrigerated }\end{array}$ & $\begin{array}{l}0.11 \pm 0.03^{b} \\
\text { (a) }\end{array}$ & Undetected & $0.10 \pm 0.03^{a}(b)$ & $\begin{array}{l}\text { (a) Lactobacillus bulgaricus, } \\
\text { (b) Miccorpussillus }\end{array}$ \\
\hline $\begin{array}{l}10 \% \\
\text { cricket, } \\
\text { refrigerated }\end{array}$ & $1.70 \pm 0.12^{\mathrm{a}}$ & Undetected & Undetected & Lactobacillus bulgaricus \\
\hline $\begin{array}{l}\text { *Standard } \\
\text { safe limit }\end{array}$ & $0.10(a)$ & $0.01(b)$ & $10(\mathrm{c}), 0.1(\mathrm{~d})$ & $\begin{array}{l}\text { (a) Bacillus subtilis } \\
\text { (b) Coliforms } \\
\text { (c) Mould, } \\
\text { (d) Saccharomyces spp }\end{array}$ \\
\hline
\end{tabular}

Values are means ( \pm Standard deviation) of triplicate determinations. Values with different superscript along the columns are significantly different from each other $(p<0.05)$. Alphabet in brackets represents organisms identified. 
Table 2d. Effect of Storage on the Microbial Content of the Experimental Diets (week 3)

\begin{tabular}{|c|c|c|c|c|}
\hline Sample & $\begin{array}{l}\text { TVC } \times 10^{3} \\
(\mathrm{Cfu} / \mathrm{g}), \mathrm{NA}\end{array}$ & $\begin{array}{l}\text { TCC } \times 10^{3} \\
(\mathrm{Cfu} / \mathrm{g}), \mathrm{MCA}\end{array}$ & $\begin{array}{l}\text { TFC } \times 10^{3} \\
(\mathrm{Cfu} / \mathrm{g}), \mathrm{SDA}\end{array}$ & $\begin{array}{l}\text { Microorganism } \\
\text { Identified }\end{array}$ \\
\hline $\begin{array}{l}\text { Corn flour } \\
\text { shelved }\end{array}$ & Undetected & Undetected & Undetected & None \\
\hline $\begin{array}{l}5 \% \text { cricket, } \\
\text { shelved }\end{array}$ & $1.21 \pm 0.11^{\mathrm{a}}(\mathrm{a})$ & Undetected & $\begin{array}{l}0.18 \pm 0.04^{b} \\
\text { (b) }\end{array}$ & $\begin{array}{l}\text { (a) Lactobacillus } \\
\text { bulgaricus, } \\
\text { (b) Muccorpussillus }\end{array}$ \\
\hline $\begin{array}{l}10 \% \text { cricket, } \\
\text { shelved }\end{array}$ & $\begin{array}{l}17.9 \pm 1.20^{b}(a \\
b, c)\end{array}$ & Undetected & $0.70 \pm 0.05^{c}$ & $\begin{array}{l}\text { (a) Micrococcus luteus } \\
\text { (b) Lactobacillus } \\
\text { bulgaricus } \\
\text { (c) Bacillus subtilis } \\
\text { (d) Aspergillusniger }\end{array}$ \\
\hline $\begin{array}{l}\text { Corn flour, } \\
\text { refrigerated }\end{array}$ & Undetected & Undetected & Undetected & None \\
\hline $\begin{array}{l}5 \% \text { cricket, } \\
\text { refrigerated }\end{array}$ & $1.11 \pm 0.11^{a}(a)$ & Undetected & $0.10 \pm 0.08^{b}(a)$ & $\begin{array}{l}\text { (a) Lactobacillus } \\
\text { bulgaricus, } \\
\text { (b)Muccorpussillus }\end{array}$ \\
\hline $\begin{array}{l}10 \% \text { cricket, } \\
\text { refrigerated }\end{array}$ & $1.67 \pm 0.30^{\mathrm{a}}$ & Undetected & Undetected & Lactobacillus bulgaricus \\
\hline $\begin{array}{l}\text { *Standard } \\
\text { safe limit }\end{array}$ & $0.10(a)$ & $0.01(b)$ & $10(c), 0.1(d)$ & $\begin{array}{l}\text { (a) Bacillus subtilis } \\
\text { (b) Coliforms } \\
\text { (c) Mould, } \\
\text { (d) Saccharomyces spp }\end{array}$ \\
\hline
\end{tabular}

Values are means ( \pm Standard deviation) of triplicate determinations. Values with different superscript along the columns are significantly different from each other $(p<0.05)$. Alphabet in brackets represents organisms identified.

Table 2e. Effect of Storage on the Microbial Content of the Experimental diets (week 4)

\begin{tabular}{|c|c|c|c|c|}
\hline Sample & $\begin{array}{l}\text { TVC } \times 10^{3} \\
(\mathrm{cfu} / \mathrm{g}), \mathrm{NA}\end{array}$ & $\begin{array}{l}\text { TCC } \times 10^{3} \\
(\mathrm{cfu} / \mathrm{g}), \mathrm{MCA}\end{array}$ & $\begin{array}{l}\text { TFC } \times 10^{3} \\
(\mathrm{cfu} / \mathrm{g}), \text { SDA }\end{array}$ & $\begin{array}{l}\text { Microorganism } \\
\text { Identified }\end{array}$ \\
\hline $\begin{array}{l}\text { Corn flour, } \\
\text { shelved }\end{array}$ & $0.01 \pm 0.00^{a}$ & Undetected & Undetected & Bacillus subtilis \\
\hline $\begin{array}{l}5 \% \text { cricket, } \\
\text { shelved }\end{array}$ & $1.19 \pm 0.07^{a}(a)$ & Undetected & $0.19 \pm 0.02^{\mathrm{a}}(\mathrm{b})$ & $\begin{array}{l}\text { (a) Lactobacillus } \\
\text { bulgaricus (b) } \\
\text { Muccorpussillus }\end{array}$ \\
\hline $\begin{array}{l}10 \% \text { cricket, } \\
\text { shelved }\end{array}$ & $\begin{array}{l}18.3 \pm 2.00^{b}(a \\
b, c, d)\end{array}$ & Undetected & Undetected & $\begin{array}{l}\text { (a) Micrococcus luteus } \\
\text { (b) Lactobacillus } \\
\text { bulgaricus (c) Bacillus } \\
\text { subtilis } \\
\text { (d) Aspergillusniger }\end{array}$ \\
\hline $\begin{array}{l}\text { Corn flour, } \\
\text { refrigerated }\end{array}$ & Undetected & Undetected & Undetected & None \\
\hline $\begin{array}{l}5 \% \text { cricket, } \\
\text { refrigerated }\end{array}$ & ${ }^{a} 1.19 \pm 0.05^{a}$ & Undetected & ${ }^{\mathrm{b}} 0.10( \pm 0.02)^{\mathrm{a}}$ & $\begin{array}{l}\text { (a) Lactobacillus } \\
\text { bulgaricus (b) } \\
\text { Muccorpussillus }\end{array}$ \\
\hline $\begin{array}{l}10 \% \text { cricket, } \\
\text { refrigerated }\end{array}$ & $1.73 \pm 0.20^{\mathrm{a}}$ & Undetected & Undetected & Lactobacillus bulgaricus \\
\hline $\begin{array}{l}\text { *Standard } \\
\text { safe limit }\end{array}$ & $0.10(a)$ & $0.01(b)$ & $10(c), 0.1(d)$ & $\begin{array}{l}\text { (a) Bacillus subtilis } \\
\text { (b) Coliforms } \\
\text { (c) Mould, } \\
\text { (d) Saccharomyces spp }\end{array}$ \\
\hline
\end{tabular}


Values are means ( \pm Standard deviation) of triplicate determinations. Values with different superscript along the columns are significantly different from each other $(p<0.05)$. Alphabet in brackets represents organisms identified.

The values for the organoleptic score taken for both children and adults are shown in Figures 1 and 2. Figure 1 shows the mean sensory characterization of the experimental diets by children. The mean scores were above average in the 7-point hedonic scale. There was no significant difference in the acceptance of the pap made from all the experimental diets, but the taste score for the corn flour was significantly lower $(p<0.05)$ when compared to the other diets. The $5 \%$ cricket diet scored highest in smell, color, taste, and texture; its high score for general appearance was not significantly different with the $10 \%$ cricket supplemented diet. The corn flour diet pap scored the least in all the parameters except for the value in the general appearance.

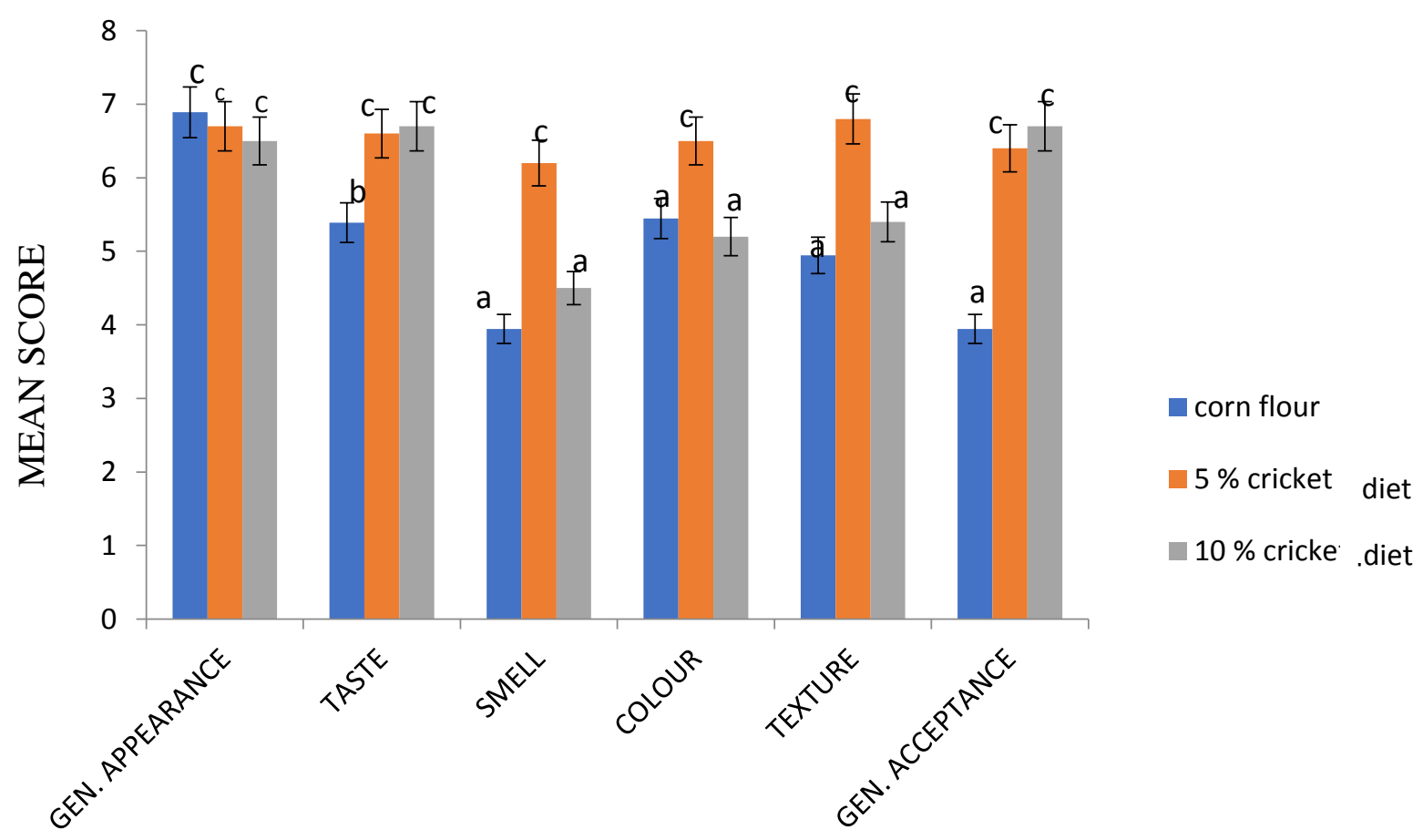

Figure 1. Sensory Characterization of Pap by Children, made from Experimental Diets.

Figure 2 which is the sensory evaluation scores of adults on pap made from the experimental diets shows that the $10 \%$ cricket diet had the highest score for general appearance while the corn flour diet was the lowest, although these differences are not significant ( $p>0.05)$. The organoleptic score for taste was not significantly different in the $10 \%$ and $5 \%$ cricket diets both were significantly higher than the corn flour for taste. The $10 \%$ cricket supplemented diet scored highest in smell $(p<0.05)$. The $5 \%$ cricket supplemented diet was rated highest for color and texture; the two parameters were not significantly different when compared in other diets. There was no significant difference between the $5 \%$ cricket supplemented the diet and the corn flour for color texture ( $p>$ $0.05)$.In general, the scores for the parameters in each sample ranged between 4.8 and 6.3 on the 7-point scale. The sensory evaluation from both children and adults were similar both in the trend of values, general appearance, and smell of the pap sample. 


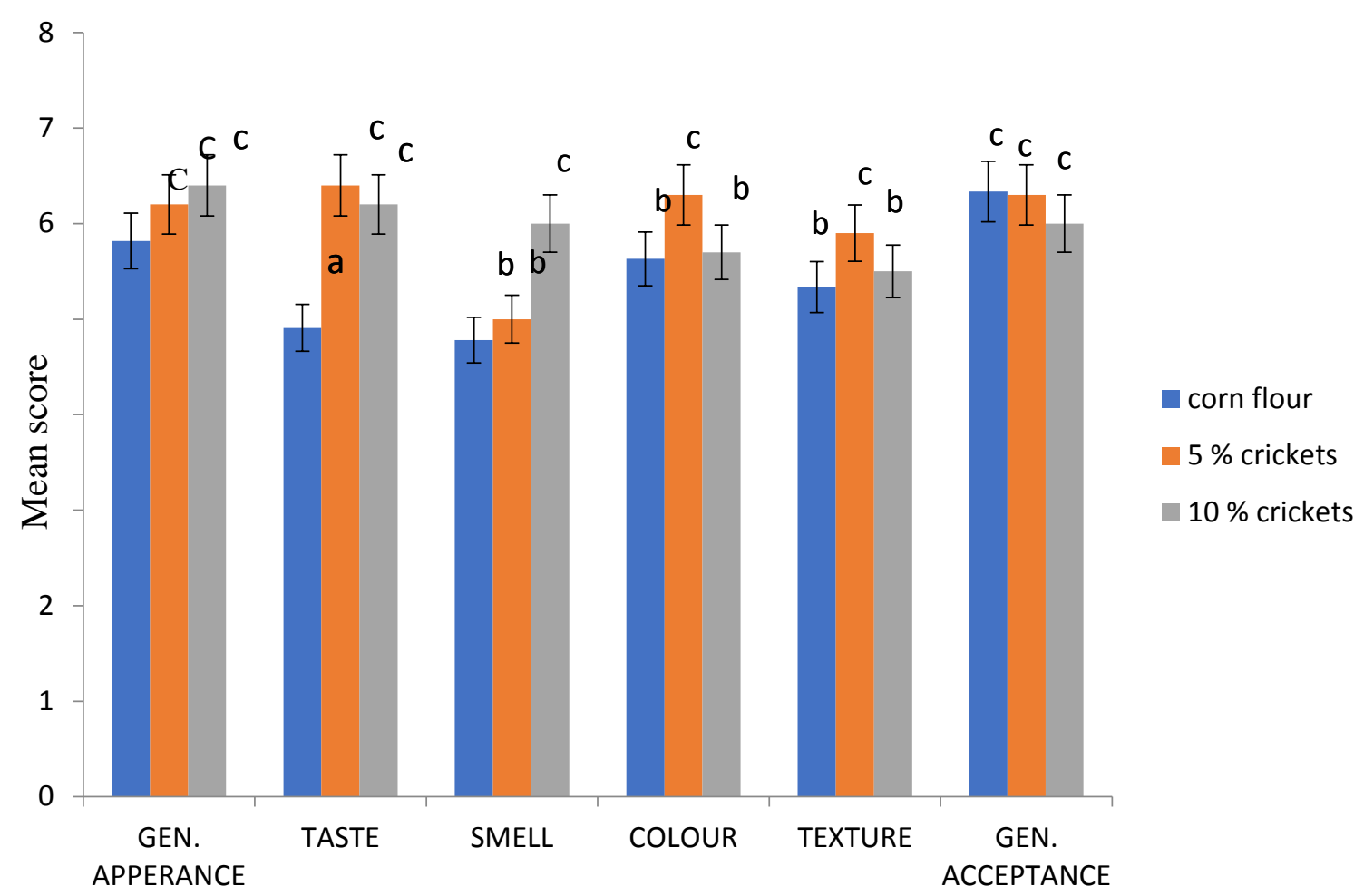

Figure 2. Sensory Characterization of Pap, by Adults made from Experimental Diets.

The physiochemical properties describe the functional properties of the diets for potential use in the food industry. The higher swelling value with $10 \%$ cricket over the other diets might indicate that the interaction of the molecules such as proteins and fats within the amylase portion of the starch granules is non covalent as similarly reported by Adegunwa. ${ }^{22}$ The reduction in solubility from the cornflour to the $10 \%$ cricket diet indicates that more soluble matter such as sugars (amylose, sucrose, and other soluble carbohydrates), soluble proteins and salts may have been leached into the solution. The higher lipid content in the $5 \%$ and $10 \%$ cricket diet compared to the cornflour diet might be responsible for the decreased solubility in the supplemented diets which is similar to the findings of Chandra. ${ }^{24}$

The higher gelatinization temperature of the supplemented diets over the cornflour diets can also be related to the report of Chandra ${ }^{24}$ that higher cooking temperature of carbohydrates increases with supplementation. This might be due to incorporation through the supplements other less polar long-chain molecules like the lipids.

The trend in wettability, which can be linked with the higher soluble matter found in the diets, might affect their storage properties as reported by Nwosu. ${ }^{21}$ In humid conditions, easily wet samples might get contaminated with microbes. The lower value of absorption of water or oil with reducing carbohydrate content is expected. The water absorption capacity of the flour sample is influenced by increasing carbohydrates content but reduced lipid content. This is similar to Adegunwa ${ }^{22}$ who reported that free sugars and some proteins are capable of binding a large amount of water through hydrogen bond formation as a result of the partial forces of attraction between $\mathrm{OH}^{-}$and $\mathrm{H}^{+}$. ${ }^{21}$

The increase in the bulk density from the corn flour through the $5 \%$ cricket diet to the $10 \%$ cricket diet may be as a result of a likely increase in relatively non-compressible components like the lipid. This implies a decrease in the compressibility of the flour sample for packaging and other related processes that require compression of food samples, and higher bulk density might also reflect higher energy value on the diet as similarly reported by Nwosu. ${ }^{21}$ 
The microbial load observed in this work (Tables 2a-2e) is similar to the findings of Ambreen ${ }^{23}$; Amadi and Kiin-Kabari ${ }^{25}$; Ajibola ${ }^{26}$. The microbial assay for week 0 , in the supplemented diets, indicated organisms that are gut-friendly and therefore not harmful. The growth of the microorganisms noticed in the diets could be as a result of growth encouraging conditions arising from supplementation (presence of higher amounts of proteins). The general reduction of the microbial load at week 1 reflects the presence of inhibitory substances like organic acids and alcohols in the food. The presence of $B$ subtilis in the $10 \%$ cricket diet is an indication of a higher tendency of the diets to spoilage. This is not unexpected as the diet is rich in proteins, amino acids, and other nutrients which make it better substrates for microbe growth. Thao observed that a higher nutrient in diets increases the microbial composition of the diets. ${ }^{27}$ The continued presence of BACILLUS subtilis and other organisms may not be of great concern since the food is to be processed by heating which destroys the microbes as reported in the findings of Ajibola. ${ }^{26}$

At the end of the $4^{\text {th }}$ week of storage, the microbial growth noticed in a most shelved sample including the corn flour was an indication of increase conditions for growth such as mesophilic temperature, and nutrients allowed for the maturity and growth of spores into adult organisms which were previously not detected. It is noteworthy that in the 4th week's assay, apart from $10 \%$ cricket diet (shelved) diet, all the diets are safe because they were void of coliform, yeast and the only occurrence of the mold was below the harmful threshold. ${ }^{28}$ However, refrigeration condition is best for the samples.

The sensory evaluations of both children and adults that are significantly above the 3.5 average scores of the 7 points sensory scale were similar to the findings of Andrew ${ }^{29}$ and Ambreen ${ }^{23}$. From the adult scores, the organoleptic evaluation for the cornflour pap was the least, and the most were the $5 \%$ cricket diet. Igyor ${ }^{30}$ stated that higher mean sensory values in the supplemented diets might be traceable to the effects of supplementation. It is possible that the blend of the roasted cricket and fermented corn flour can enhance the sensory receptors because they might have emitted volatile substances. This might have reached an optimum at the $5 \%$ protein supplementation of the corn diet with the cricket flour. The organoleptic values for both children and adults were similar, suggesting the diets were acceptable and beneficial to all age groups.

\section{CONCLUSION}

The pap made from the $5 \%$ cricket supplemented flour was more acceptable from the sensory evaluation compared to the pap made from corn flour, and $10 \%$ cricket supplemented diets. The biological parameters showed that higher growth performance, total protein intake was found in the $10 \%$ cricket supplemented diet. Moreover, the physiochemical parameters of the diets were all significantly different $(p<0.05)$ except for the swelling index. Finally, studies on the shelf life showed that refrigeration was a better efficient method of storage when compared to the shelf storage at room temperature (27$\left.29^{\circ} \mathrm{C}\right)$.

\section{REFERENCE}

1. Ambuehl, S. An offer you cannot refuse? Incentives change how we think. Job market paper.Department of Economics, Stanford University, Canada. 2015.

2. United Nations International Children Emergency Fund (UNICEF). Nigeria: Malnutrition-Over 1000 children die daily says Federal Ministry of Health. 2016; (http: all africa.com stories 201607170052.htmL). Retrieved on 21 March 2017.

3. Food and Agriculture Organization (FAO). The state of food and agriculture 2013: food systems for better nutrition. FAO, Rome, Italy. 2013; 23.

4. Okai, D.B., Boateng, M., Ewool, M.B., Ankamaa, D. \& Osarumwense, S.O. Nutritional evaluation of some new maize varieties: effects on growth performance 
and carcass traits of albino rats. African Journal of Food Agriculture and Development. 2015; 15: 10306-10316.

5. Abdoulaye, T., Bamire, A. S., Wiredu, A. N., Baco, M. N., \& Fofana, M. Project Community Surveys. Characterization of Maize Producing Communities in Bénin, Ghana, Mali, and Nigeria. International Institute of Tropical Agriculture (IITA), Ibadan, Nigeria. 2012; 55.

6. Igah, S.A. Target food sources for formulating complementary/Supplementary foods for weaning purposes - a review. Bayero Journal of Pure and Applied Sciences. 2008; 1(1): $20-27$.

7. Wang, D., Bai, Y.T., Li, J.H. \& Zhang, C.X. Nutritional value of the field cricket (Gryllustestaceus Walker). Journal of Entomologia Sinica. 2004; 11: 275-283.

8. Rumpold, B., \& Scluter, O. Potential and challenges of insects as an innovative source for food and feed production. Innovative Food Science and Emerging Technologies, 17,1-11.

9. Van-Huis, A., Van Itterbeeck, J., Klunder, H., Mertens, E., Halloran, A., Muir, G., \& Vantomme, P. Edible insects: future prospects for food and feed security. FAO Forestry Paper 171. Rome, Italy: FAO. 2013; 78-100.

10. Luc, N., Isaac, N., \& Frank, F. The potential for entomophagy to address undernutrition. Ecology of Food and Nutrition. 2014; 1: 1-9.

11. Kelemu, S., Niassy, S., Torto, B., Fiaboe, K., Affognon, H., Tonnang, H., Maniania, N.K. \& Ekesi, S. African edible insects for food and feed: inventory, diversity, commonalities and contribution to food security. Journal of Insects as Food and Feed. 201;5 1(2): 103-119.

12. Lensvelt, E. \& Steenbekkers, L. Exploring consumer acceptance of entomophagy: a survey and experiment in Australia and the Netherlands. Ecology of Food and Nutrition.2014; 53(5 ):543-561.

13. Lacey, R. Crickets as food: The perceptions of and barriers to entomophagy and the potential for widespread incorporation of cricket flour in American diets, senior honors thesis program. The Environmental University of Michigan, Michigan, United States. 2016.

14. Hamerman, E. Cooking and disgust sensitivity influence preference for attending insect-based food events. Appetite. 2016; 96: 319-326.

15. Belluco, S., Losasso, C., Maggioletti, M., Alonzi, C., Paoletti, G., \& Ricci, A. Edible insects in a food safety and nutritional perspective: a critical review. Comprehensive Reviews in Food Science and Food Safety.2013; 12: 296-313.

16. Verbeke, W. Profiling consumers who are ready to adopt insects as a meat substitute in a Western society. Journal of Nutrition. 2014; 39: 147-155.

17. Onwuka, G.I. Food analysis and instrumentation theory and practice (First Edition) Napthali prints; Lagos. 2005; 45-70.

18. Sandra, P.C., Jesus H.G \& Dario, A.T. Physiochemical characteristics and function properties of vitabosa and soya bean. Journal of Food science and Technology. 2013; 32: 1-8.

19. Udensi, B. A., \& Onuora, J. O. Chemical and functional properties of some soya bean flours in Nigerian market. Book of abstracts, 16th Annual Conference of NIFST, Enugu .1992); $26-30$.

20. Nwosu, J. N., Ogueke, C. C., Owuamanam, C. I., \& Onuegbu, N. The effect of storage conditions on the proximate and rheological properties of soup thickener brachystegiaenrycoma (Achi). Report and Opinion Journal.2011; 3: 5-9.

21. Ukpabi, U. J. \& Ndimele, C. Evaluation of the quality of gari produced in Imo State Nigeria. Nigerian Food Journal.1990; 8: $105-110$.

22. Adegunwa, M. O., Alamu, E. O., .Bakare, H. A., \& Godwin, P.O. Effect of fermentation length and varieties on the qualities of corn starch (ogi) production. American Journal of Food and Nutrition.2011; 12: 2157-2158. 
23. Ambreen, A. S., Amer, M., Saeeda, R. \& Shahzada, A. S. Microbial count and shelf life of phalsa (Grewiaasiatica) juice. Pakistani Journal of Agricultural Research. 2015; 28:4-10.

24. Chandra, S., Singh S. \& Kumar, D. Evaluation of functional properties of composite flours and sensory attributes of the composite flour biscuit. Journal of Food Science and Technology.2015; 52(6): 3681-3688.

25. Amadi, E.N. \& Kiin-Kabari, D.B. Nutritional composition, and microbiology of some edible insects commonly eaten in africa, hurdles and future prospects: a critical review. Journal of Food Microbiology Safety and Hygiene.2016;1, 107.

26. Ajibola, C. F., Fagbemi, T. N. \& Oluwatooyin, F.O. Nutritional quality of weaning food formulated from maize gruel 'ogi' and crayfish using combined traditional processing technology. Advances in Research. 2016; 6(4): 1-11.

27. Thao, M.H, Tony, H. \& Bhesh, R.B. An Innovative approach to extend the shelf life of cottage cheese curds using food grade $\mathrm{CO}_{2}-\alpha$-cyclodextrin complex powder: $\mathrm{A}$ preliminary study. Journal of Food Processing and Preservation. 2017; 42: 2-5.

28. Food and Drug administration (FDA). Defect levels handbook. (available at www.fda.gov/food/guidance compliance. 2011 (Latest update September 2011).Accessed December 2011. (available at www.ars).

29. Andrew, K. A., Patrick O., Sophie O., Peter Y., Juliet, H.M. \& Juliana, M. Sensory acceptability of sorghum peanut blend (spb) and corn soy blend plus (csb+) by young children with moderate acute malnutrition in Karamoja, Uganda. Journal of Food Research. 2014; 3: 2-6.

30. Igyor, M. A.,Yusufu, P. A. \& Sengev I.A. Evaluation of physiochemical, functional and sensory properties of fermented fura powder supplemented with soy. Nigerian Food Journal, .2011;29:1-4. 